An International Journal of Language, Literature and Gender Studies (LALIGENS)

Ethiopia

Vol. 3 (2), Serial No 8, May, 2014:146-166

ISSN: 2225-8604(Print) ISSN 2227-5460 (Online)

http://dx.doi.org/10.4314/laligens.v3i2.9

\title{
SEX VARIATIONS IN THE USE OF TABOO EXPRESSIONS IN IGBO COMMUNITY: A MANIFESTATION OF GENDER INEQUALITY
}

OMEGO, CHRISTIE U., Ph.D.

Department of Linguistics and Communication Studies

University of Port Harcourt

Port Harcourt, Rivers State, Nigeria

E-mail: omegochristie@ yahoo.com

Phone: +2348033504741

\section{Abstract}

This study examined sex variations in taboo expressions in Igbo culture area and argued that sex variations in taboo expressions in Igboland is an indication that gender inequality still operates in Igbo community despite all efforts aimed at eliminating all forms of discrimination on the basis of sex. To carry out this study, the researcher adopted a descriptive survey method. The methods of data collection used were interview, personal observation and the researcher's intuition as a member of Igbo speech community. Secondary data was collected through library research. A total of 48 fluent speakers of Igbo who inhabit the Igbo speaking areas were purposively selected for this study. The data collected were descriptively analyzed. The result of the study proved that sex is a 
strong linguistic variable that affects speech in Igbo community and that women in Igboland are forbidden from using certain taboo expressions, especially in gatherings comprising men and women. This paper, therefore, concluded that the differences observed in the speech of men and women in Igboland serve as an evidence of inequality between men and women in Igboland despite various attempts aimed at putting an end to all sorts of discrimination on the basis of sex.

Key Words: community, culture, inequality, expression, language, sex, variation, taboo

\section{Background to the Study}

A speech community, as Trudgill (1994, p.100) defines it, is a totality of linguistic varieties used by a particular community. Romaine (1994, p.22), however, describes a speech community as a group of people who do not necessarily have the same language, but share a set of norms and rules for the use of language.

The Igbo are culturally homogenous. They form a group which interact in patterned ways and share beliefs, values, goals and norms, and have a feeling of membership. Their rich cultural heritage is reflected in their proverbs, songs, music, dances, drama, paintings, drawings, marriage ceremonies, festivals, chieftaincy installations, etc. Through the use of language, all these aspects of culture which bind the Igbo people are made meaningful, expressible and operational. The Igbo language is, thus, a unifying factor of the Igbo culture and has proved an efficient and useful tool for the dissemination of the Igbo culture from generation to generation.

In some cultures, linguistic differences occur in the speech of men and women. According to Trudgill (1985), it is known from linguistic research that in many societies the speech of men and women differ. The linguistic differences between men and women's speech reflect separate sub-cultures. Hence, we talk of men's language and women's language. In Igbo culture, as in many other cultures, there are appreciable differences between the speech of men and women. In the 
traditional past and, in fact, until the present, several ethnographic accounts of some ethnic groups in Nigeria show that men play a dominant role vis-à-vis women in decision making in the family and society at large. Evidence from anthropology has also proved that men and women differ in their speeches because there is sex variation in language.

This paper, thus, argued that the differences which exist in the use of taboo expressions by men and women in Igbo society are a reflection of the culture of the Igbo and an evidence of gender inequality operating in the society in the 21 st century.

Before we embark on this discussion, it might be pertinent to begin with an attempt to explain the following key terms: language, culture and sex as a way of providing a basis for our discussion. We shall start with an explanation of the concept 'language'.

Language is a medium of communication between two people or a group of people. According to the Encyclopedia Britannica (1960), language is an 'arbitrary' system of vocal symbols by means of which human kind, as members of social group and participants in a culture interact and communicate. This definition stresses the fact that language is a phenomenon that is produced by man's vocal system for communication purposes. In Smith's (1969) opinion, language is:

A learned, shared and arbitrary system of vocal symbols through which human beings in the same speech community or sub-culture interact and hence communicate in terms of their common cultural experience and expectations (p. 104).

Smith's definition suggests that language, as a learned phenomenon, is peculiar to a particular speech community, or a people that share the same culture. Womack (2001, p.154) also defines language as the human ability to encode culturally defined meanings in sound and to combine units of sound to generate infinite new meanings through the application of rules. This definition, as Oluwabamide (2003, p.41), 
observes lays emphasis not only on man's unique ability to use language, but also on the essence of rules in language.

Culture, on the other hand, refers to a pattern of human behaviour which is learned by the members of the society and transmitted from one generation to another. One of the earliest definitions of the term 'culture' was offered by Edward Tylor in 1871. He describes culture as that complex whole which includes knowledge, beliefs, arts, morals, laws, customs and any other capabilities and habits acquired by man as a member of society. Sanderson (1988) takes a broader perspective to the explanation of culture and says that culture is the total life ways characteristic of the members of a society, including tools, knowledge and patterned ways of thinking and acting that are learned and shared and not the direct product of biological inheritance.

Sex, according to Yul- Ifode (2011, p.2), is a biological distinction between men and women. The use of the term 'sex' as a rough synonym for gender is often misleading. Although gender is one of the most misunderstood categories in the literature, it has nothing to do with sex. As Trask (1996) observes:

There is no particular connection between gender and sex. Sex is a matter of biology, while gender is a matter of grammar, and there is no earthly reason why sex should be involved in gender distinction (p. 41).

Gender in many gender languages shows no connection with sex. Trask cites the example of a North American language, Navalio, which has ten genders, but sex had no part to play. There are, however, some languages (especially non-European languages) in which sex does correlate with gender. One of such languages includes the Australian language called Dyirbal.

According to Wardhaugh (1986, p.309), sex is biologically determined, whereas gender is a social construct (but one heavily grounded on sex) involving the whole gamut of psychological, social and cultural differences between males and females. In other words, 
whereas gender borders on masculine feminine, and neuter; sex differences refer to male and female.

It should be pointed out that the use of the expression "language and sex" implies that language use is sexist in the sense that women's speech differ from that of men.

\section{Statement of the Problem}

In Nigeria, currently, women are looked upon as weak, not only physically, but even intellectually, an attitude of mind which, according to Plato, is entirely against nature (cf. Ndu 1995). Nigeria is, today, saddled with many development problems and one of them is the issue of gender inequality. Gender inequality manifests in our use of language (as in taboo expressions such as are found in proverbs/ idioms, songs, greetings, etc.) in spite of all efforts aimed at eliminating all forms of discrimination on the basis of sex. The issue of gender equity has been the concern of many countries of the world including Nigeria. In a bid to achieve this, in 1995, the United Nations (UN) held a World Conference in Geneva where member states agreed to eliminate all laws that discriminate against women (Awake. 2000, p.4). The aim was to engender a sense of gender equality. But in spite of these efforts, we tend to encourage gender inequality through the use of language in our community.

Therefore, the question which this study set out to address is whether sex variation in taboo expressions is not an evidence of inequality between men and women in Igbo culture area?

\section{Purpose of Study}

The purpose of this study was to investigate language variation in Igboland on the basis of sex. The following are specific objectives:

1. to find out whether taboo expressions exist in Igboland;

2. to ascertain if there are certain taboo expressions men use which women do not use in Igboland, and 
3. to find out the reasons for the differences, if any, found in the speech of men and women in Igboland.

\section{Research Questions}

The following questions are designed to provide answers to this research:

1. Do taboo expressions exist in Igboland?

2. Are there certain taboo expressions men use that women do not use in Igboland?

3. What are the reasons for the differences, if any, found in the speech of men and women in Igboland?

\section{Scope of the Study}

This study covers only sex variations in taboo expressions. It specifically covered areas such as proverbs, songs and greeting/ address forms as they occur in the speeches of men and women. The area of coverage is the Igbo culture area, and to be specific Owere nshi ise 'five villages of Owerri'.

\section{Theoretical Background}

Differences in language use on the basis of sex have been observed by many authors. Holmes (1993, P.164) states that women and men do not speak exactly the same way in any community. As Trask (1996) also observes,

Perhaps one of the most obvious social divisions in society is that between men and women, and this division, not surprisingly, is often strongly represented in speech. In some languages, the difference is so great that men and women actually use different words, different pronunciations or different grammatical forms. This happens, for example, in Japanese in which some words are different (p. 86). 
Women are claimed to be more linguistically polite than their male counterparts and in formal discussions, they are said to observe the necessary features of language, using the proper lexical items, simple and more discernible than the male speech form, which is always coded in idioms and proverbs. Holmes (1993, p.171) also notes that women use more standard speech forms than men because they are more status-conscious than men. Women are more aware of the fact that the way they speak signals their social class, background or social status in the community. An investigation into English, according to Trask (1996, p.86), also reveals that women spend more time talking about clothes and children, while men talk more about cars and sports. The women are also said to make frequent use of a number of admiring terms rarely used by men. Such include: divine, cute, adorable, and thrilling. They also use colour terms more than men. Men are, however, said to use swear words much more than women and interrupt far more than women. It was further discovered, that women use more tag questions than men. Mesthrie (2000) quotes Holmes (1993) as stating that:

Women and men talk differently. Research in Britain, America and New Zealand reveals similar genderbased patterns of discourse. Women appear cooperative facilitative participants, demonstrating in a variety of ways their concern for the conversational partner, while men tend to dominate the talking time, interrupt more often than women, and focus on the content of the interaction and the task at hand at the expense of attention to their addressees.

This analysis or comparison, thus, reveals that language use in some societies is sexist, and as Trask (1996) also observes:

Feminists have often pointed to these differences as evidence of the subordinate position of women in our society: Women are expected to be 'lady-like', to refer to the pronouncements of men, before asserting 
anything of substance and to confine their discussions to topics considered trivial by men (p. 87).

Writing on the differences between men's and women's languages, Mesthire (2000) also cites Jesperson (1922) as stressing that:

Men have a great many expressions peculiar to them, which the women understood, but never pronounce themselves. On the other hand, the women have words and phrases which the men never used or they would be laughed to scorn. Thus, it happens that in their conversations it often seems as if the women had another language than the men.

The differences in male and female speeches manifest in many areas. In the area of phonology, for instance, there are noticeable differences in a variety of languages. Wardhaugh (1986, p. 311) cites an example of Gross Ventre, an American language of North East United States, where the whole men use palatalized dental stop.

Similarly, in Zulu, there is a phonological differentiation in the speech of men and women. Women, for example, are prohibited from pronouncing words such as amanzi, because it contains [Z], but can say amandabi which does not contain [Z] (see Wardhaugh 1986). Also in Zulu, according to Adekoye (1990, p.34), it has been reported that a wife was not allowed to mention the name of her father-in-law or his brothers, or she might be put to death if she broke the taboo. For example, if the name of the brother in-law contains the sound / $\mathrm{z} /$, this might mean that apparently the wife in question would not be able to use the word containing the sound.

There are also noticeable differences in the speech of men and women in the area of morphology. Trask (1996, p.86), for instance, cites an example of Koasati, a language spoken in Louisana, where many words have different endings when used by women and men. For example, the word Lakawhol 'lift it' is used by women, while Lakawhos is used by men. In other words, men can pronounce [s] as inflectional ending of the verb, but not women. 
English, according to Wardhaugh (1986, p.312), also makes certain distinctions of sex-based kind. Examples are actor or actress, waiter or waitress, master or mistress, porter or portress, etc. These morphologized distinctions depend on the entity referred to.

\section{Methodology}

This study adopted a descriptive approach as research method. This method allowed or enabled the researcher to collect information from selected respondents who grew up in Igboland and speak the Igbo language and knows the culture of this group of people.

The research population comprised all Owere-Igbo speaking people who inhabit the Owerri Capital Territory in Imo State, Nigeria which has a population of $3,934,899$, according to 2006 population census (Cf. Okwor 2012).

The study adopted cluster sampling method with multi-stage selection. This method involves breaking down the population into sub-groups and a sample taken from only a portion of the sub-groups at a time until all the groups have been sampled. Owerri capital territory has five villages; namely; Umиororonjo; Umиоуima, Umиоdu, Umuonyeche and Amaawom. In each of these five villages, the purposive sampling method was also used to select only the respondents needed for the study.

Purposive sampling technique was employed to enable the researcher select and interview elderly men and women who are the custodians of the Igbo language and culture in the areas sampled.

\section{Data Presentation, Analysis and Discussion of Findings}

The data collected from respondents are presented, analyzed and discussed in this section. The responses from our interviewees were meant to answer the research questions raised in section one of this research.

Research Question 1: Do taboo expressions exist in Igboland? 
To this question, respondents gave some examples of taboo expressions that exist in Igboland. According to them, In Igboland, taboo words include vulgar words such as words dealing with the private parts of the human body (i.e. genital organ), words dealing with delicate subjects, such as $\underline{o s u}$ 'outcast', $\underline{o h u}$ ' 'slave', etc.; words felt to be too strong or powerful such as onwu 'death'; swear words, etc., as we have seen on the table above Women do not freely use these taboo words, especially in social or public gathering or polite company. These taboo words are usually not called by their actual names by women in such gatherings. Their real names are avoided and more pleasant, mild or less shocking words are sometimes used in referring to them. Hence, some taboo words and expressions are the motivation for euphemism. According to Fromkin and Rodman (1998, p.432), the existence of taboo words or ideas stimulates the creation of euphemism (see also Crystal, 2000). Euphemism is the use of a pleasant, mild, indirect word or phrase that replaces or serves to avoid frightening or unpleasant subjects. Euphemism is, therefore, a term used to describe the act of avoiding a taboo word in favour of a more pleasant one.

In Owere-Igbo, for instance, euphemistic synonyms or words are used mostly by women to replace taboo words in public or 'polite company'. Table 1 also shows a small selection of euphemistic synonyms in Owere-Igbo normally used to replace taboo expressions.

\section{Table 1: Taboo Expressions in Igbo Community}

\begin{tabular}{|c|c|c|c|c|c|}
\hline $\mathbf{S} / \mathbf{N}$ & Word & Gloss/Meaning & $\begin{array}{c}\text { Euphemistic } \\
\text { Synonym }\end{array}$ & $\begin{array}{c}\text { Literal } \\
\text { Meaning }\end{array}$ & Gloss \\
\hline 1 & àkwùna & 'flirting' & Igba ama & $\begin{array}{l}\text { 'to be seen } \\
\text { outside' }\end{array}$ & 'flirting' \\
\hline 2 & Inwu & 'to die' & Ihāfū. & $\begin{array}{l}\text { 'to go'/ 'to } \\
\text { leave' }\end{array}$ & 'to die' \\
\hline 3 & Igbu & $\begin{array}{l}\text { 'to kill/eliminate } \\
\text { (a human being) }\end{array}$ & iwè hũ ṇdhu & $\begin{array}{l}\text { 'to remove } \\
\text { life' }\end{array}$ & $\begin{array}{l}\text { 'to } \\
\text { kill/eliminate' }\end{array}$ \\
\hline
\end{tabular}




\begin{tabular}{|l|l|l|l|l|l|}
\hline 4 & osu & 'outcast' & $\begin{array}{l}\text { nde he }{ }^{-} \text {oma } \\
\text { mere- }\end{array}$ & $\begin{array}{l}\text { 'the lucky } \\
\text { people' }\end{array}$ & 'outcast' \\
\hline 5 & inu.nso & 'to mensurate' & $\begin{array}{l}\text { inwe } \\
\text { obia }\end{array}$ & $\begin{array}{l}\text { 'to have a } \\
\text { visitor' }\end{array}$ & $\begin{array}{l}\text { 'to } \\
\text { menstruate' }\end{array}$ \\
\hline 6 & ime- & 'pregnancy' & Iriju afo . & 'to be filled' & 'pregnancy' \\
\hline 7 & $\begin{array}{l}\text { ikwà } \\
\text { iko }\end{array}$ & 'illicit love act' & ime-he aparì & $\begin{array}{l}\text { To do a } \\
\text { stupid thing' }\end{array}$ & $\begin{array}{l}\text { 'illicit love } \\
\text { act' lo }\end{array}$ \\
\hline 8 & ira otu & 'to have sex' & ira hu & $\begin{array}{l}\text { 'To sleep } \\
\text { with' 'To make } \\
\text { love' }\end{array}$ \\
\hline
\end{tabular}

Although language is shared adequately by men and women in Igboland, the Igbo culture tends to pose restrictions on the use of taboo expressions by women. Women do not often use taboo words and expressions as freely as men do. They rather make more extensive use of the euphemistic synonyms of the taboo words. The extensive use of euphemism by women in Igboland, according to the majority of our respondents, stems from the fact that women are believed to be more linguistically polite and reserved than their male counterpart. This finding supports Lakor's (1975, P.55) assertion as summarized in Coates (1986, p. 21) that "women do not use off colour or indelicate expressions and that women are experts at euphemism". Jesperson (1922,P.245) also cited in Coates (1986,P.22) holds the view that there can be no doubt that women exercise a great and universal influence on linguistic development through their instructive shrinking from coarse and gross expressions and their preference for refined and (in certain spheres) veiled and indirect expressions. He goes on to the particular case of swearing and notes that among the things women object to in language is swearing, but maintains that those circles in which swearing is common is found much more extensively among men than among women. Thus, while the men can talk with impunity about the private parts/sexual organs or acts, women in Igboland do not talk about them openly. In fact, a woman who discusses the sexual organs or sexual acts is regarded as a prostitute and as such does not 
attract respect from men. A young man, on the other hand, can use vulgar words without attracting resentments from his fellow men.

Other taboo areas which women do not participate in include presentation of kola nuts. They do not also pour libation no use expressions associated with it. These are meant for the men folk because some form of incantations (language) are involved which only men are permitted by the society to use. Women do not also participate in masquerades because a lot of secrets are involved which only men are deemed capable of handling. In some kind of masquerade performance, women are not allowed even to watch.

According to Okoye (1999),

Men talk forcefully and have commanding and authoritative tone. A man being the head can use or talk any how without being seen as a taboo. But women are restricted to some language use in Igboland which are found in rituals and masquerade cults (p. 45).

Title-taking (or Chieftaincy installation) is also an exclusive preserve of men. The men are the 'ofor' title holders. In giving such titles, it is believed that there are secrets involved which only men can keep and languages which only men are allowed to utter. Age-grade system is an executive organ in the Igbo traditional setting and it constitutes of men born during a particular period. Women do not form or join age grades. As Umeh (2005, p.282) rightly observes,

Socially, women are not allowed to belong to clubs as their male counterparts. When we talk about agegrade in Igbo communities, often times, it is made up of male folks. It is absurd, in fact, an abomination for a woman to be the head of any village or town in Igboland. Even though, in some case, daughters (umuada) could intervene in serious matters in their communities of birth, their contributions most times are not reckoned with. 
Research Question 2: Are women forbidden from using certain taboo expressions in Igboland?

In answering the second research question, the native speakers interviewed gave a number of proverbs, songs, and greetings and indicated those which men could use freely, but women cannot use freely, especially in public or social gathering. Proverb is an important element of oral transmission of the Igbo culture which serves the needs of oral tradition and aid in preserving and spreading Igbo culture. There are some proverbs which Igbo women cannot say in public. These include proverbs containing taboo words or expressions (i.e. words belonging to private parts of the body). According to Umeh (2005, p.283), an Igbo woman no matter her status in the society is not safe to use some Igbo proverbs, especially those that pertain to male or female genital organs to stress her point in public speech. She cites the following proverbs as example,

(1) Ana-aso nwaanyi ikpu ukwu anya, o ga-ara onwe ya?

'Why must we fear a woman with big virgina, will she make love to herself?'

(2) Onye amu di mma, amaghi ihe onye ibi na-ahu.

'A man with a healthy penis does not know what his fellow man with an enlarged scrotum is passing through'.

Some proverbs, on the other hand, show that a woman is expected to be submissive to her husband. If she does not, she runs the risk of breaking that marriage. Nothing is, however, said about the husband. Hence, women occupy subordinate positions. They are as follows:

(1) Nwànyi lelià di yà anyà ike àkpo yà nku.

'If a woman neglects or insults her husband, she suffers'.

(2) Nwanyi anaghi akpa oke ala.

'A woman does not negotiate a land boundary.' 
The proverb above (i.e.2) suggests that in Igbo culture, a woman does not own any property. Whatever she has is her husband's because she belongs to the man. Hence, it is a taboo for a woman to negotiate for sale of land while her husband is still alive. All these proverbs go to prove that women occupy subordinate positions in Igboland. Another proverb which suggests that a woman is subordinate to her husband is (3)

(3) Mma nwanyi wu di ya

A man is the woman's beauty'

This proverb implies that in Igbo culture, no matter how beautiful or wealthy a woman is, she is not recognized if she is not married, and in marriage, according to Ndu (1995,P.46), the man is the head of the household. He rules over both the wife and the children.

Generally, the Igbo traditional society is male-dominated and, it is also believed that women are talkative and, therefore, would not be trusted with secrets. Hence, the Igbo culture enshrines the linguistic differences between men and women into proverbs. Many proverbs abound in Igbo which also show that men do not believe in women as people who can keep secrets and as such should not be trusted. Such proverbs include:

(4) Nwanyi wu akwa, anaghu ehiwe ya n' ishi

'A woman is a kind of pillow; you cannot use it to support your head'.

(5) Ekwurekwu mere nwanyi agbaghu ahu onu

'It is because of talkativeness that women do not grow beards'.

These proverbs support the fact that one cannot trust women with secrets. This may be one of the reasons why all the traditional positions of authority from the kindred to the village level are occupied by men. Women and children are almost treated as nonentities. 
A good competent of the oral transmission of culture is the folklore. Folklore comprises folktale and folksongs. In traditional Igbo setting, the folktale normally takes place during moonlight play sessions (usually after night meals) or informal gatherings comprising both adults and children. The folktales do not only entertain the in-group, but also teach morals and transmit behaviour patterns because the narrator (usually an elderly man) often ends the folktale in such a way that a good character is rewarded, while a bad character is punished. In such gatherings, a woman is not expected to be the narrator.

Folksong or music here refers to indigenous or ethnic folk music which has evolved through the process of oral transmission. According to Ifionu (1982, p.41), an examination of different categories of Igbo music demonstrates vividly that Igbo music grows out of human experiences and is also an inter- human phenomenon which operates as part and parcel of almost all Igbo cultural activities. Such activities include egwu nwa 'music associated with childbirth', egwu eji eku nwa 'cradle song or lullabies', egwu eji alu nwanyi 'music associated with marriage', egwu ozo 'music connected with 'ozo title ceremonies', egwu ekpe 'Ekpe cult music', egwu ikpe 'satirical songs' and so on (see Ifionu 1982). These various categories of music show that music features in most Igbo cultural activities.

Songs associated with birth, for instance, are hardly sung by men. It is the women that sing such songs at the arrival of a newborn baby. When a woman gives birth in Igboland, it is the womenfolk's duty to announce this by shouting the 'oro-onu'. It is usually shouted by the mother -inlaw of the woman that gave birth to a baby. The shout is meant to attract other women in the neighbourhood who come around to sing and dance. The family offers the crowd kolanut and $n z u$ 'edible species of clay soil' which is expected to attract money or gift in return or in appreciation of the birth of the baby. It is only women that partake in the singing. According to Ojukwu (1990),

...men could only come to the scene to welcome the new-born baby as well and sit down to watch the women celebrate and sing the popular song (p. 89). 
Although men may sing birth songs or lullabies, it is the women that are noted for that. Women do not, however, sing war songs. They are, rather, sung by men or warriors either for victory or to incite themselves to action or to instil fears in their opponents. During funerals also, men and women have different songs to perform. The men's songs are peculiar to them and are not used by women.

The fact that war songs, Ekpe cult songs, and ozo title songs are restricted to the men folk, while birth songs, lullabies, etc., are restricted to the women folk shows that there are differences in men and women's speech in Igboland.

Table 3: Examples of Folklore (songs) in Igboland

\begin{tabular}{|c|c|}
\hline For women (cradle songs/lullabi) & For men (war songs) \\
\hline $\begin{array}{l}\text { 6. Onye muru nwa n' ebe akwa } \\
\text { Egbe muru nwa n' ebe akwa } \\
\text { Weta uziza, weta ose } \\
\text { Weta amara ogololo ofe } \\
\text { Ka umu nunu racha aka } \\
\text { Ka okpo ofufu kpogbuo ha } \\
\text { Egwu eh egwu eh... }\end{array}$ & $\begin{array}{l}\text { 7. Nzogbu nzogbu } \\
\text { Enyimba enyi } \\
\text { Nzogbu enyimba enyi } \\
\text { Zogbuo nwoke ... }\end{array}$ \\
\hline $\begin{array}{l}\text { 8. } \\
\text { Onye nuru olu nwa eh } \\
\text { Bia eh onye nuru olu nwa } \\
\text { Mee ngwa ngawa o bu so ofu } \\
\text { Onye nwa }\end{array}$ & $\begin{array}{l}\text { 9. Gowon itiwe tiwe } \\
\text { Titee nwa agu n'ura } \\
\text { Gowon itiwe tiwe titee nwa } \\
\text { agu n' ura } \\
\text { Mgbe nwa agu tetere, } \\
\text { ebelebe egbula }\end{array}$ \\
\hline
\end{tabular}


In greeting, sex is a major factor that affects the pattern of address. This implies that in most cases, men are addressed differently from the female folk depending on the situation. Differences also exist as nature has endowed specific social functions to a particular sex. For instance, handshakes are common among men, while hugging and embracing are associated with females. A woman cannot imitate a hand shake when exchanging greetings with a man in Igbo land as it is seen as a taboo. As Njoku (1990, p.35) notes, women are expected to use two hands when responding to a hand shake from men, especially elderly men. Women are also expected to bow down when greeting a titled man. Men only nod their heads. Sometimes, speech or verbal greetings accompanied bowing (see also Njoku 1990, p.38).

In Igbo culture area, the choice of address form varies according to the social characteristics of the speaker such as his social class, age, sex and setting (see Ellah 1995). Men are known to use forceful words in greeting or in addressing a gathering. Okoye (1999, p.35) observes that for the men, the following form of address is obtainable in Igboland:

Greeting: Cha cha cha cha Igbo kwenu!

Response: Yaa

Greeting: Rie nu!

Response: Yaa

Greeting: Nuo nu!

Response: Yaa

Women, on the other hand, do not use these forceful words in greeting or in addressing a gathering. They, rather, say the greetings softly and, in some cases, lengthen the greetings to show politeness, as in:

Greeting: Nde nga anyi nnu anuola ooo

"Our people, I greet you all ooo / well done"

Greeting: Nnu abiala ooo 
"You are welcome"

Umeh (2005, p.283) agrees with Okoye (1990) by asserting that:

A woman is prohibited by the custom and tradition of the Igbo people from bellowing her public audience before she can make her speech. While her male counterpart must start his address by first bellowing thus, Igbo kwenu!! Kwezuenu!!!. a woman will just start by first recognizing the presence of all the men, whom she sees as her husbands, her lords, and masters no matter their ages. Hence, she starts in a subtle and submissive voice by saying 'ndi dim

\begin{tabular}{|c|c|}
\hline For Women & For Men \\
\hline 10. i. Di m i noola & Nwaanyi ibola? \\
\hline 'Good day my husband.' & 'Women have you woken up?' \\
\hline ii. I boola nna m ukwu & iv. Nwaanyi oma, I ri kpa ole? \\
\hline 'Good morning my master' & 'How are you good woman'? \\
\hline
\end{tabular}

Research Question 3: What are the reasons for the differences in the speech of men and women, if at all they differ in Igboland?

Research question 3 sought to find out the reasons for the differences in the speech of men and women in Igboland. The following answers which form our data bank were got from the respondents.

The Igbo community, according to some of the respondents, expects appreciable language use from the women since they perform the role of modeling correct behaviour mostly for children's speech. Proper 
use of language by children depicts good family background and the role usually falls on the women who spend more time with the children. The women are expected to inculcate in the children good moral conduct, make them shy away from using swear words, vulgar words and other taboo expressions. The mother is at the centre of all these and the chief method of teaching under this system of education and socialization is by example and means of learning is imitation.

From our findings, it can be seen that whereas very few respondents, i.e. 8 representing $29 \%$ of the respondents saw sex variation in taboo expressions as normal and accepted way of life of the Igbo because a woman is supposed to be decent even in speech, the majority of the respondents, i.e.40 (or $71 \%$ ) saw the differences simply as a case of gender inequality which should not be allowed to persist in Igboland. Language, they stressed, is a not a static phenomenon. It is dynamic and positive changes can be welcomed whenever it is deemed fit. The $21^{\text {st }}$ century is a period when changes are expected. Hence, different nations are making efforts to eradicate all forms of discrimination against the womenfolk. Nigeria in general and Igboland, in particular, should not be left behind in this race.

Our respondents are also of the view the belief that women are inferior is also transferred into the use of language. This view of women being naturally dependent on the men, it must be pointed out, was carried from ancient times into the early Christian era and planted in religious thought. As Ndu (1995, P.47) also states, the Bible enjoins women to be subject to their husbands, saying 'wives submit yourselves unto your husbands for the husband is the head of the wife'.

Husbands, according to $\mathrm{Ndu}$, are merely charged to 'Love your wives'. The Bible goes on to describe the women as the glory of the man (1 Corinthians 11:7) and, thus, 'learn in silence with all subjection'; (1 Timothy 2:11). From this biblical account, it is evident that women are subject to their male counterpart. In Igbo traditional system, women are not only dependent on their husbands, but accorded inferior positions. Division of labour was based on sex and age. Men farm, hunt, fish and go to war, while women cook, trade, 
etc. A child receives traditional education according to his or her sex. Girls are taught how to cook, take care of their babies, prepare themselves as housewives, etc. They are taught feminine occupations such as spinning, weaving, hair plaiting, etc., while boys learn the basic occupations of their elders such as hunting, farming, craft, fishing, pottery, smiting, etc., to enable them win bread for their wives or families.

\section{Conclusion}

In this study, we have tried to establish different domains in which men and women differ in their use of language, especially in taboo expressions. We found out that men and women differ in their use of taboo and swear words, proverbs / idioms, greetings, folklore, etc., and that what is accepted as right among the male counterpart is frowned at when a woman does it. The belief that women are inferior is also transferred into the use of language which seems to suggest that men and women speak different languages even within the same language and within the same linguistic group.

\section{References}

Oluwabamide, J. (2003). Ethnolinguistics: The relation of language to culture. Lagos: LisJohnson Resources Publishers.

Adekoye, M.A. (1990). Language in multicultural context. In Emenanjo, E. N. (ed.). Multilingualism, minority languages, and language policy in Nigeria. Agbor: Central Books Limited. $239-247$.

Crystal, D. (2000). Dictionary of linguistics and phonetics. Cambridge: Cambridge University Press.

Emeana, Ray. (2001). The theatre and Igbo culture: A Proposal. Jonlac 2, $44-52$.

Fromkin, V. \& R. Rodman (1998). An introduction to language, 6th Edition. New York: Harcourt Brace College Publishers. 
Goates, J. (1986). Woman, man and language: A sociolinguistic account of sex differences in language. London: Longman.

Greenberg, J. (1968). The Science of Linguistics In: H. E. Fried (ed.) Readings in Anthropology. New York: Thomas Crowed Company $347-363$.

Holmann, C. H. (1972). A handbook on literature. New York: Bobbs - Meriil Company Incorporated.

Holmes, J. (1992). An Introduction to sociolinguistics. London: Longman Group Ltd.

Ifionu, A. (1982). The Role of Music in Igbo Culture. An Ethnomusiociological explanation. In Ogbalu F.C. and E. N. Emenanjo (eds). Igbo language and culture 2. Ibadan: Oxford University Press.

Jesperson O. (1922). Language: Its nature, development and origin. New York: W.W. Norton.

Mesthrie, R. (2000). Introducing sociolinguistics, Edinburgh: Edinburgh University Press.

Ndu, Eme C. (1985). Colonialism and gender inequality in Nigeria. A paper presented to the Department of Political and Administrative Studies, University of Port Harcourt.

Nwoga, I. D. (1975) "Approval of Igbo Proverbs and Idioms. In Emananjo E. N. (ed.) Igbo Language and culture. Ibadan: Oxford University Press.

Okwor, L.N. (2012). Radio and indigenous languages in Nigeria: The case of Igbo. An Unpublished MA Thesis submitted to the Department of Linguistics and Communication Studies, University of Port Harcourt.

Yul-Ifode, S. (2011). A cross-linguistic study: Sex and language variation in selected Nigerian communities. The International Journal of Humanities. Vol 9, Pp1-14 